\title{
Resistance sources for wheat aphid : An update
}

\author{
S.D. PATIL*, A.P. PADHYE AND SUBHASH KATARE ${ }^{1}$ \\ Agricultural Research Station, NIPHAD (M.S.) INDIA \\ ${ }^{1}$ Directorate of Wheat Research, KARNAL (HARYANA) INDIA
}

\section{ARITCLE INFO}

Received : 03.08 .2016

Accepted : 28.09.2016

\section{KEY WORDS :}

Wheat, Triticum aestivum, Rhopalosiphum padi (L), Hydroxamic acids, Non preference, Resistance
*Corresponding author: Email : saurushrutu@gmail.com

\section{ABSTRACT}

Wheat (Triticum aestivum L.) is a major crop with largest area under cultivation in India and plays a significant role in economic stability of the country. Many insect pests attack wheat in India, severe damage is caused by aphids as serious pest of wheat crop which cause yield losses either directly (35-40\%) by sucking the sap of the plants or indirectly $(20-80 \%)$ by transmitting viral and fungal diseases. They can multiply very rapidly under favourable conditions on leaves, stems and inflorescence. The infestation causes severe distortion of leaves and inflorescence and can significantly decrease the yield through direct feeding. The production of chlorophyll (green colour) is prevented by the attack of aphid resulting in curling of leaves and delayed head emergence causing improper maturity of grains. The aphid incidence level differed in different cultivars of wheat. The resistance of crop is an index of the balance that exists between the preference of the pest for crop and its antibiosis against it. The mechanical barriers possessed by the plants which prevented insects from feeding or ovipositing on them. The infestation significantly affected the root dry weight, number and height of tillers and number of spikes per head. Leaf epicutticular wax, ultra structure and leaf trichome were different on susceptible wheat cultivar and resistant cultivar. Leaf trichome density and position may act as a physical obstracle to the Russian wheat aphid feeding. An increased amount of glutamic acid, glutamine, alpha amino butyric acid, phenylalanine and proline and less methionine, produce resistance in wheat plants against aphids. Hydroxamic acids ( $\mathrm{Hx}$ ) have been shown to be a major biochemical mechanism of resistance of wheat to aphids, acting through antibiosis and feeding deterrency.

How to view point the article : Patil, S.D., Padhye, A.P. and Katare, Subhash (2016). Resistance sources for wheat aphid: An update. Internat. J. Plant Protec., 9(2) : 628-631, DOI : 10.15740/ HAS/IJPP/9.2/628-631. 